\title{
Identification Local Food and Levels of Community Preference at The Border Region of Sangihe Islands District
}

\author{
Meivie Lintang ${ }^{1}$, Payung Layuk ${ }^{1}$, Sudarti ${ }^{1}$, Joula Sondakh ${ }^{1}$ \\ ${ }^{1}$ North Sulawesi Agricultural Technology Research Center
}

\begin{abstract}
The research aims to find out the types, levels of people's preferences as well as factors that affect local food consumption, especially carbohydrate source food in Marore archipelago. The research was conducted in Marore sub-district, namely Kawio and Marore Village which carried out by using survey methods. The results showed that types of local food farmed by the people of Kawio and Marore villages are cassava, daluga, taro yam, sweet potato, banana, and sago as a source of carbohydrates but the farming system and post-harvest handling are still traditional. The level of food preference of people between Kawio and Marore villages are difference. Based on education level, there is a significant real negative correlation for bananas, based on the age, the correlation is significant for cassava and bananas, and based on income per capita there is no correlation. The level of preference for food is generally from ordinary to like very much in the border area of Sangihe Islands influenced by the availability of food, the consumption patterns of local community and the community's access to get food. Cassava is the most preffered type of food besides rice, so cultivation and post-harvest system must to be optimized.
\end{abstract}

\section{Introduction}

Sangihe Islands regency is an area of North Sulawesi Province which has a border area that is Marore sub-district, located in Kawio and Marore villages. As an archipelago, the main livelihood of the local people is fishermen, but still depends on the basic needs of local foodstuffs in the region [1]. The availability of local food in the borders area greatly affects food security. Some of the main issues that are developing related to food security in the

Border Area include socioeconomic disparities between people living in Indonesia's border area and neighboring countries, relatively low agricultural productivity due to information limitations and technology dissemination, inadequate infrastructure, production infrastructure and land and inter-island distribution facilities that can reach the entire region, the inability for the poor to provide adequate amounts of food so that aspects of nutrition and food safety have not been a major concern [2]. Food security is a measure of how well a region can fill its people with enough food at all times. This goal is achieved when people have physical and economic access to sufficient, safe, and nutritious food to support their

Corresponding author : mlintang71@gmail.com 
dietary needs and enable an active and healthy life. This definition is broken down into 4 dimensions namely food availability, food access, food utilities and food stability [3].

Food security according to the FAO, is a guarantee of constant access to the world's population, both countries and regions to get food in the amounts necessary to maintain an active and healthy lifestyle [4]. This definition also applies when everyone has access both physically and economically at all times to fulfill their diet including safe and nutritious foods, and at the same time provide food preferences for an active and healthy life [5]

Many factors cause food insecurity such as poverty, low access to basic social services, and the incompetence of some public policies [6] In general, the definition of local food is food produced, marketed, and consumed by local or local communities. The term "Local Food" has multiple and some-times conflicting definitions. In most cases it means that the food was grown in close physical proximity to the consumer (e.g., a few miles from the point of sale, was produced in the same city, or in the same state) [7]. It can also mean food sold in an alternative food market. Local food definition is also closely related to emotional and social relationships with food origin influenced contextual factors [8]. Another important issue to be addressed is the development of local food in disaster situations. Given the capacity of planning in advance and the feasibility of providing local food where possible, priority would be given to acquire food from local small agriculturalists [9]

Local food in the border area especially the archipelago area is different and has its own characteristics compared to local food in non-island areas. The people of the archipelago have a culture of consuming local food that tends to differ from non-islanders, influenced by the main types of food that have been inherited by their ancestors In the Sangihe archipelago in general, the main food is sago, but in the Marore archipelago area has its own specificity [10]. The consumption patterns of border communities are strongly influenced by the level of people's preference for the type of food which available at the area.

Consumer preferences are defined as subjective (individual) tastes, measured by the level of usability over the consumption of products or services. This theory gives consumers the power to rank such products or services [11]. Differences or similarities in food preferences, caused by biological, psychological, cultural, and societal factors [12]. Consumers' response to food products are determined by four different components, that are the sensory characteristics of a product, general response consumer to a product, cognitive component and response is affected by a behavioral component which involves the persons' intentions or actions for future behavior [13]. Prosocial helping behavior captures at least part of the tension between embeddedness, on the one hand, marketness and instrumentalism, on the other, that brings to light both consumer preferences for local food and what drives their preferences [14].

The major determinant of food choice is hunger, but if we have options what people choose to eat is not determined solely by physiological or nutritional needs [15]. The consumers' gender, age, and education level, along with perception, emotional motivations, and selection of information sources about healthy eating should also be taken into account [15]. Subjective values can determine people's food choices, and these values can be influenced by a variety of factors including risk, delay, reward type, and number [16]. Individuals may consider the time to get the type of food and the amount of food they will get with cost or effort, what risks they may take (e.g. risk of heart attack or weight gain), and which foods they like [17]. Food preferences interact with different food choice factors (such as advertising, functional, health, price, sensory and socio-cultural) and sociodemographic features of the consumer (such as age, economic condition, education, gender, region of residence and size of the place of residence), which again interacts with the frequency of food intake [12] 
Kawio and Marore border areas in addition to having local food types that have historically existed in the area such as tubers, sago and bananas, there are also food stuffs supplied from outside such as rice, flour and other instant foodstuffs. Information about the identification and level of local food preference does not yet exist, so this study was conducted. The research aims to find out the types of local food that exist in the Marore region, the level of people's preferences as well as the factors that affect the level of preference for local food, especially carbohydrate source food in the border area of Sangihe Islands Regency.

\section{Research methods}

The research was conducted in Marore sub-district, namely Kawio Village and Marore Village in 2017. The samples in this study were households in Kawio Village and Marore Village with a total of 80 respondents. The sampling method used is a non-probability sampling method because the population studied the number and identity of the members is unknown. The sampling was done accidentally, the samples used in this study were 40 people from Kawio Village and 40 people from Marore Village. The data used in this study is primary and secondary data. The method used to collect primary data with interviews uses structured questionnaires and direct observations. Secondary data is obtained through the retrieval of data coming from agencies/institutions related to research.

The data collected is the type of local food source of carbohydrates that exist in Kawio and Marore villages, whether farmed or not. The data collected is the type, the part used and the processed food type. Preference data is collected for food types namely daluga tubers, taro, cassava, sweet potatoes, bananas, sago, rice and noodles, and the preference level uses a favourite level score with a score of 1 very dislike, 2 dislikes, 3 ordinary, 4 likes and 5 very likes. The way of categorization and analysis of research variables is presented in Table 1. The data obtained was statistically analysed with the Chi Square analysis to see the correlation between people's preference levels by region, and Spearman's analysis of the correlation of education levels, age and per capita income using data from Kawio village specific preference levels.

Table 1. The categorization of research variables

\begin{tabular}{|l|l|l|}
\hline Variable & Category & Analysis \\
\hline Region Type $\backslash$ & Village & Descriptive \\
\hline Last Education & 0. No / have not finished primary & Descriptive \\
& school & \\
& 1. SD / equivalent & \\
& 2. SMP / equivalent & \\
& 3. SMA / equivalent & \\
& 4. Diploma I II & \\
5. Diploma III / Academy & Descriptive \\
& 1. $<20$ & \\
& 2. $1-30$ & \\
& 3. $1-40$ & \\
& 4. $1-50$ & \\
& $5.1-59$ & Descriptive \\
& $6 .>60$ & \\
\hline Income per capita & 1 Low $(<689,000)$, & \\
& 2 Medium $(689,000-$ & \\
& $1,178,000)$, & \\
& 3. High $(>1,178,000)$ & \\
\hline
\end{tabular}




\section{Results and discussion}

\subsection{Characteristics of Research Sites}

Marore Islands sub-district, has an area of $4.45 \mathrm{~km} 2$ with an area of Marore village of 2.60 $\mathrm{km} 2(58.0 \%)$ and Kawio village $1.54 \mathrm{~km} 2(35.0 \%)$. Geographically the village of Marore is located at $04^{\circ} 44^{\prime} 14^{\prime \prime} \mathrm{U} 125^{\circ} 28^{\prime} 42^{\prime \prime} \mathrm{T}$ and Kawio village is located at $04^{\circ} 40^{\prime} 16^{\prime \prime} \mathrm{U} 125^{\circ}$ $25^{\prime} 41^{\prime \prime} \mathrm{T}$, a distance of approximately 37 nautical miles. To reach the village it takes approximately 2 days from Manado the capital of North Sulawesi Province. The population of Marore in 2016 was 1,630 with a population of 662 in Marore Village, Kawio Village 493 and Matutuang Village of 475. Based on gender, the composition of the population in Marore Village is 339 male, female 323; the population in Kawio Village is male 225, female 240, Matutuang male 240 and female 235 [18]. The population of Marore archipelago by livelihood is presented in Figure 1.

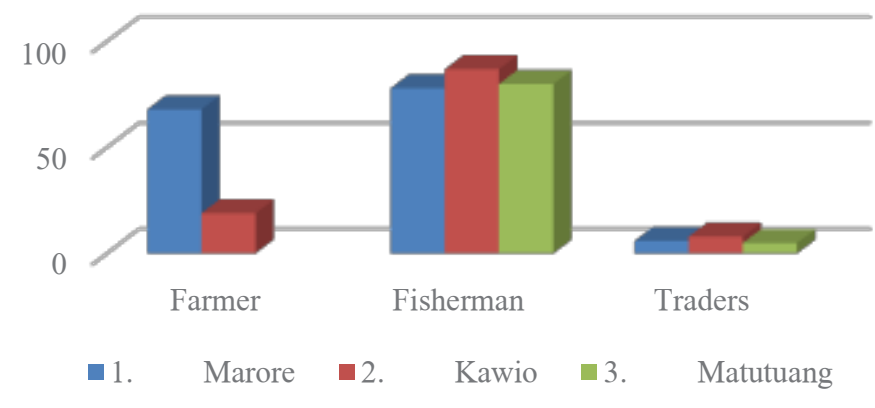

Fig. 1. Population by means of livelihoods in Marore Islands District, 2016 [17]

Data presented in figure 1 shows that the majority of the population in Marore sub-district has livelihoods as fishermen. This is because Marore sub-district is an archipelago, and the land that is attempted to grow small. Farmers in Marore and Kawio villages are generally coconut farmers. Kawio village consists of 2 islands namely Kawio Island and Kemboleng Island. Kawio Island is hilly and kemboleng village tends to be flat. The types and characteristics of kawio villagers' work are more influenced by environmental determinants, where living on the coast and isolated islands have made them the largest fishermen as the main jobs, while the smallest parts are farmers. The side jobs of the community are farmers, farm workers, builders (inside and outside villages such as Manado City, Tahuna, and Talaud), civil servants and retirees with a small number, namely 8 people.

\subsection{Identification of Local Food Types in Marore District}

The development of border villages in order to match the condition of the village needs to be seen the potential of existing villages. The potential of the village is natural resources and human resources that can be utilized for the survival of the local villagers. The potential of the village can be distinguished in physical and non-physical potential. The main agricultural commodity in Marore Sub-district is coconut. The main product which is marketed to other island is copra. Table 2 shown the type of local food in Marore Sub-district. 
Table 2. Types of local food and its operations in Marore District

\begin{tabular}{|c|c|c|c|c|}
\hline Location & Local food & Type & $\begin{array}{l}\text { Used plant } \\
\text { part }\end{array}$ & $\begin{array}{l}\text { Type of processed } \\
\text { food }\end{array}$ \\
\hline \multirow[t]{6}{*}{ Kawio Village } & Tubers & $\begin{array}{l}\text { Daluga } \\
\text { (Daluga } \\
\text { Cambodia, white } \\
\text { daluga } \\
\text { and green daluga) }\end{array}$ & tuber & Boiled daluga \\
\hline & & Cassava & $\begin{array}{l}\text { Tuber, } \\
\text { leaves }\end{array}$ & $\begin{array}{l}\text { Boiled cassava, fried, } \\
\text { cassava sago, cassava } \\
\text { panada }\end{array}$ \\
\hline & & Taro yam & tuber & Boiled taro, fried \\
\hline & & Sweet potato & tuber & Boiled taro, fried \\
\hline & Banana & $\begin{array}{l}\text { Copper banana, king } \\
\text { banana, shoe banana }\end{array}$ & Fruit, leaves & $\begin{array}{l}\text { Fried banana, boiled } \\
\text { banana }\end{array}$ \\
\hline & Sago & Baruk sago, sago & starch & Flour, omelette sago \\
\hline \multirow[t]{2}{*}{ Marore village } & Tubers & Cassava & $\begin{array}{l}\text { Tuber, } \\
\text { leaves }\end{array}$ & $\begin{array}{l}\text { Boiled cassava, fried, } \\
\text { cassava sago, cassava } \\
\text { panada }\end{array}$ \\
\hline & Banana & Shoe banana & Fruit, leaves & $\begin{array}{l}\text { Fried banana, boiled } \\
\text { banana }\end{array}$ \\
\hline
\end{tabular}

Source: Primary Data, 2017.

Local food sources of carbohydrates can be grouped into two groups of grains and groups of tubers. According to the grouping of central statistics agency, which belongs to the group of grains are rice, corn and wheat, while the group of tubers are cassava, sweet potato, sago, and other tubers.

The data presented in Table 2 shows that in Marore sub-district there are local food resources in the form of tubers, bananas and sago. From the results of surveys and interviews it turns out that the variety of local food farmed in kawio village was more than in Marore Village. This is due to the condition of the topography and the location of farmland in kawio village is different from in Marore Village. The topography condition in Kawio village is hilly and flat. The type of land in kawio village especially on Kawio Island is sandy clay soil and in Marore Village is partially sandy except in the mountainous area. The state of marore sub-district topography with a slope of land $>40$ or $1,760 \mathrm{Km} 2$. The results of the study [1] soil in kawio village of $\mathrm{N}$ content and soil phosphorus in Kawio was relatively low, and potassium content was classified as high ( $\mathrm{N}$ content is about $0.15 \%$, phosphorus $0.05 \%$ and potassium $22.66 \%$ ). This means that the content of organic matter tends to be low, but people in Kawio village were accustomed to farming with existing land conditions and rarely use inorganic fertilizers. Land utilization in Kawio and Marore villages was about 100-1300 m2. The farm land in Marore village is in the mountains away from the settlement, while the farm site in Kawio village is around the settlement.

Cassava is a local variety and its processed products are only consumed and not marketed. Daluga yam is farmed in Kawio village, spread most in Kemboleng village. Daluga was widely spread in the North Sulawesi archipelago region, a type of tuber belonging to the family Araceae, growing on sandy swamps with a tuber weight of about $0.18-2 \mathrm{~kg}$, containing high carbohydrates of about $32.53 \%$. Daluga tuber is an alternative food crop for the population of Sangihe. However, it has been displaced by changes in the main food consumption patterns to rice. The community poorly farms sweet potatoes and taro potatoes in this area so sweet potatoes are often imported from outside the island. Banana species in Marore village are not very diverse compared to those in Kawio village. Local food cultivated by the local community is traditionally done in the way of both land processing, 
planting and maintenance system. Instant food such as instant noodles and bread, already in the Borders area, is imported from outside the village and is widely consumed by the community.

\subsection{Community Preference Level}

The focus of food security is not only on the provision of regional-level food but also the provision and consumption of regional and household-level food even individuals in meeting their nutritional needs [19]. People's food preference is the ability of individuals or people to choose food raw materials that meet macro and micronutrients at affordable prices. Food preferences are formed as a process involving individual internal factors (experience and knowledge of health benefits), external factors (food characteristics), and social, cultural and economic status [20]. Food availability in a region strongly affects people's access to local food. Table 3 present the level of community perception in getting food in Marore subdistrict.

Table 3. Community perceptions of the ease of getting food

\begin{tabular}{|l|c|c|c|c|c|}
\hline Commodity & Very easy & Easy & Enough & Difficult & Very difficult \\
\hline Rice & 10 & 66 & 8 & 16 & 0 \\
\hline Daluga yam & 22 & 18 & 10 & 48 & 0 \\
\hline Taro yam & 26 & 36 & 16 & 18 & 0 \\
\hline Cassava & 74 & 12 & 14 & 0 & 0 \\
\hline Sweet potatoes & 2 & 8 & 16 & 64 & 8 \\
\hline Sago & 32 & 34 & 14 & 20 & 0 \\
\hline Banana & 54 & 28 & 14 & 2 & 0 \\
\hline Bread & 0 & 32 & 58 & 4 & 2 \\
\hline Noodles & 0 & 34 & 56 & 4 & 2 \\
\hline
\end{tabular}

Source: Primary data 2017, processed.

Table 3 showed that the most easily obtained types of carbohydrate sources in a row are cassava and banana ( $>40 \%$ ), followed by sago, sweet potato, yam daluga and rice, while the hardest to obtain are sweet potatoes. This indicates the availability of types of cassava and banana food in high society compared to sweet potatoes. Sweet potatoes are still little cultivated by the local community. The ease of obtaining this food can affect people's preferences.

\subsubsection{Preference levels by region}

Marore village and Kawio village are located in one sub-district that closed each other. The research showed that the two village had different economy level that influenced to consumption pattern include the level of preference. The level of people's food preference towards food types, especially as a source of carbohydrates based on marore village area and Kawio village is presented in figure 2.

Figure 2 shows that in Kawio Village the highest preference level value is found in the commodity of daluga tubers with ordinary scores, while in Marore Village on cassava commodity with a highly liked score. While in Marore Village on cassava commodity with a very good score. This is because in Kawio Village in addition to cassava, daluga tubers are widely cultivated in the village, while in Marore Village only cassava. The distance between Kawio Village and Marore Village is close, but little number daluga tubers are marketed in 
Marore Village. The results of statistical analysis of correlation between food preference and regional origin to carbohydrate food are presented in table 4 .

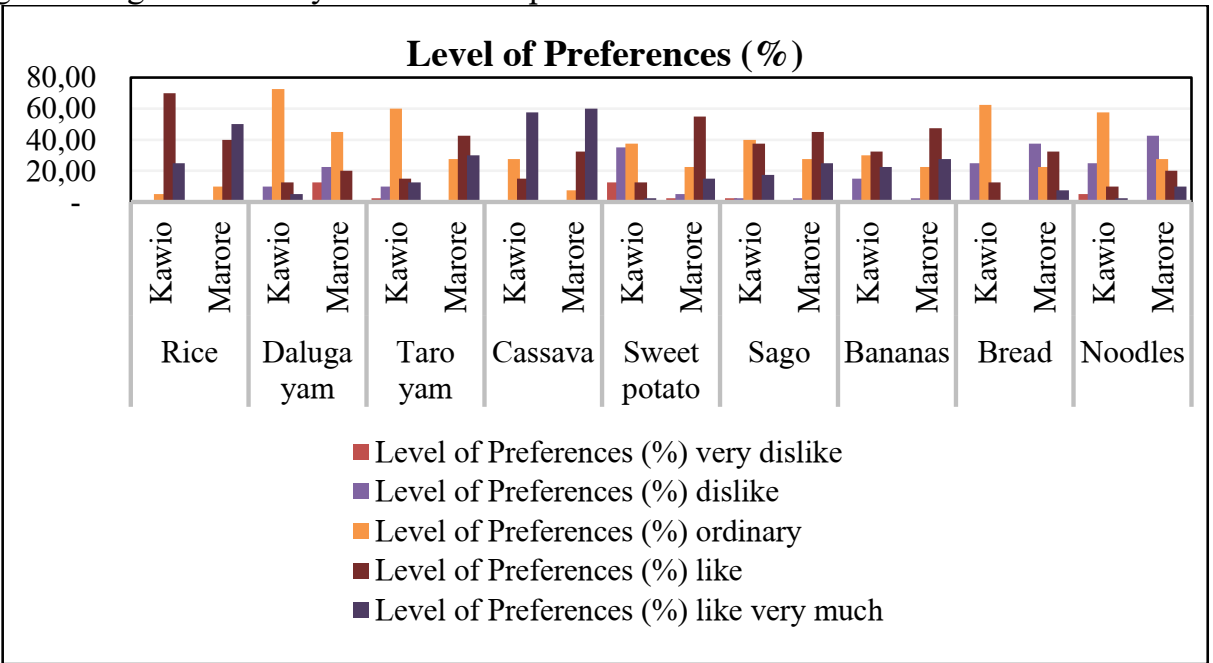

Source: Primary Data, 2017.

Fig. 2. The level of community preference for food types by region

Table 4. Results of correlation analysis between food preferences and regional origin on food Carbohydrates

\begin{tabular}{|c|c|c|c|}
\hline Types of Food & Region & P-Value & Description \\
\hline \multirow[t]{2}{*}{ Beras } & Kawio & \multirow[t]{2}{*}{0.026} & \multirow[t]{2}{*}{ There's a connection } \\
\hline & Marore & & \\
\hline \multirow[t]{2}{*}{ Daluga tubers } & Kawio & \multirow[t]{2}{*}{0.016} & \multirow[t]{2}{*}{ There's a connection } \\
\hline & Marore & & \\
\hline \multirow{2}{*}{$\begin{array}{l}\text { Sweet potato } \\
\text { taro }\end{array}$} & Kawio & \multirow[t]{2}{*}{0.001} & \multirow[t]{2}{*}{ There's a connection } \\
\hline & Marore & & \\
\hline \multirow[t]{2}{*}{ Cassava } & Kawio & \multirow[t]{2}{*}{0.028} & \multirow[t]{2}{*}{ There's a connection } \\
\hline & Marore & & \\
\hline \multirow[t]{2}{*}{ Sweet potato } & Kawio & \multirow[t]{2}{*}{0.000} & \multirow[t]{2}{*}{ There's a connection } \\
\hline & Marore & & \\
\hline \multirow[t]{2}{*}{ Sago } & Kawio & \multirow[t]{2}{*}{0.604} & \multirow[t]{2}{*}{ No connection } \\
\hline & Marore & & \\
\hline \multirow[t]{2}{*}{ Banana } & Kawio & \multirow[t]{2}{*}{0149} & \multirow[t]{2}{*}{ No connection } \\
\hline & Marore & & \\
\hline \multirow[t]{2}{*}{ Bread } & Kawio & \multirow[t]{2}{*}{0.002} & \multirow[t]{2}{*}{ There's a connection } \\
\hline & Marore & & \\
\hline Noodles & Kawio & 0.025 & There's a connection \\
\hline
\end{tabular}

Source: Primary data 2017, processed

Based on results in Table 4, there is a relationship between the level of carbohydrate source food preference and the origin of kawio and marore villagers for local food types of daluga tubers, sweet potatoes, cassava, taro yam, rice, bread and noodles. In this type of sago and banana food there is no relationship. This indicates that there are differences in local food compared to local bananas and sago foods, although both types of food are easy to obtain. There is a difference of preference, because in Kawio village many cultivated types of yam tuber, suitable with data presented in table 1. Condition of Kawio's land is more 
supportive to farming compare than marore village's land, so the community is easy to get it.

Another reason that caused the consumption patterns of Marore village and Kawio village have differences was economy level, which Marore village was better compare with Kawio village, so could affect the level of people's preference for food type. For preference to rice, some people of Marore Village express very like, while in Kawio village only at the level liking. This is because rice distribution in Marore village are more open and people's access to get rice is greater, although rations for subsidized rice in Kawio Village also exist. Marore village also is the center of sub-district government, and rice supply from outside is larger than kawio village. The transportation path that entered Marore village is higher frequency with the arrival of ferry and pioneer ship in rice distribution. Marore village had a village market, while in Kawio not have. The extence of market influence the availability of rice for Marore's people and has an impact on the high level of preference for this type of food. For the type of food from outside such as noodles and bread, the number respondents in Marore village with a very like preference, had high score compared to kawio village. It caused by the influence of markets, shop in Marore village that market bread, and noodle.

The results of correlation analysis of preference level in bananas and sago showed that have no relationship with the region. The score of preferences of peoples of both villages are generally equal only on ordinary scores and likes. This is because both commodities are available in both villages, although for sago commodities began to decrease availability.

\subsubsection{Preference levels by education level}

Food perception and preference are influenced by human personality characteristics. Besides, food preferences and choices are closely related to demographic factors such as age, gender, income, and education levels, and linked to cultural factors [12]. From the results of the study, the relationship between education and the level of food preference in Kawio village is presented in figure 3 .

\section{Level of Preferences}

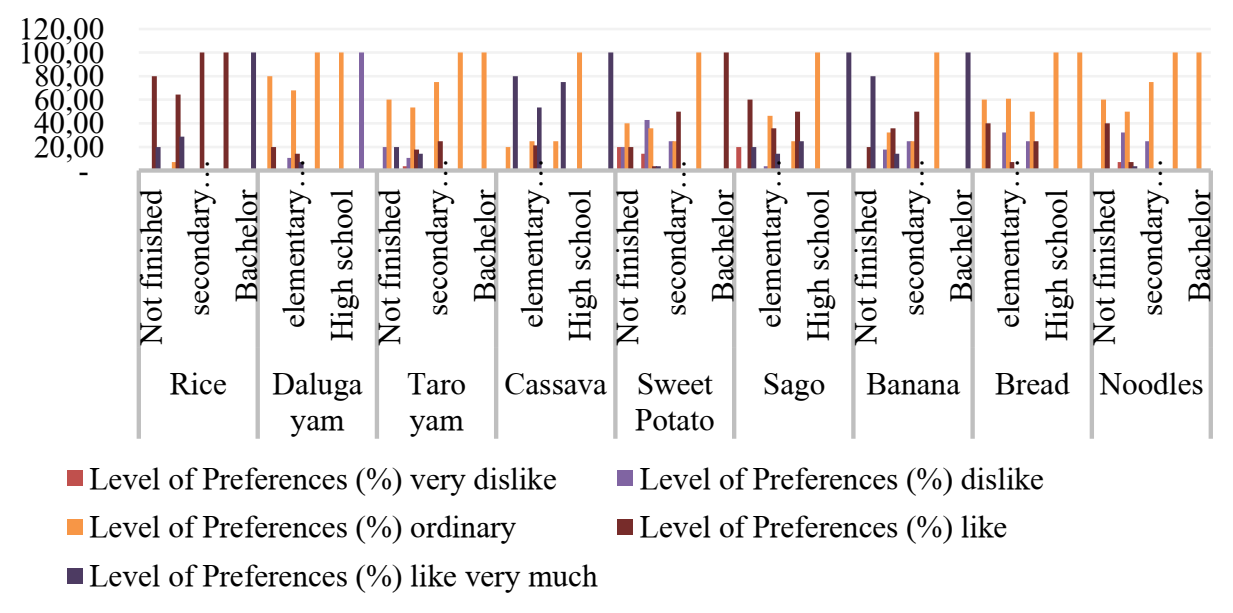

Fig. 3. The level of community preference for food types by last education

Figure 3 shows that the respondent's level of preference for rice and cassava spread on an ordinary level until like very much. The highest score on likes for rice, and cassava score 
highest at ordinary level. On daluga tubers, banana and bread, level of preference was spread on dislike until like very much, on cassava level of preference was spread on ordinary until very like, sweet potato, taro yam, noodles and very dislike until like very much. From the data (see fig 3.) shows that people in Kawio village with different levels of education like the local food in the village. The relationship between the food preference of carbohydrate sources and the last education based on statistical analysis results is presented in table 5 .

Table 5. Results of correlation analysis between food preferences and last education In Kawio Village

\begin{tabular}{|c|c|c|}
\hline Types of Food & $\begin{array}{c}\text { p-value } \\
\text { (r-value) }\end{array}$ & Description \\
\hline Rice & $\begin{array}{c}0.923 \\
(0.016)\end{array}$ & Weak correlation is not significant \\
\hline Daluga tubers & $\begin{array}{c}0.139 \\
(-0.238)\end{array}$ & Negative correlation is not significant \\
\hline Taro yam & $\begin{array}{c}0.808 \\
(-0.040)\end{array}$ & Negative correlation is not significant \\
\hline Cassava & $\begin{array}{c}0.196 \\
(-0.209)\end{array}$ & Negative correlation is not significant \\
\hline Sweet potato & $\begin{array}{c}0.323 \\
(0.160)\end{array}$ & Weak correlation is not significant \\
\hline Sago & $\begin{array}{c}0.994 \\
(-0.001)\end{array}$ & Negative correlation is not significant \\
\hline Banana & $\begin{array}{c}0.032 \\
(-0.340)\end{array}$ & Real negative correlation/ significant \\
\hline Bread & $\begin{array}{c}0.387 \\
(-0.140)\end{array}$ & Korelasi negatif tidak significant \\
\hline Noodles & $\begin{array}{c}0.281 \\
(-0.175)\end{array}$ & Korelasi negatif tidak significant \\
\hline
\end{tabular}

Source: Processed from Primary Data, 2017.

The data presented in Table 5 shows that there is a significant relationship with the real negative correlation rate for banana commodities with a $p$ value of 0.032 , while other types of food are insignificant. Bananas are a type of food that is favored by all circles regardless of education, beside as a daily table fruit, bananas in Kawio Village are also processed as snack food in the morning and evening, in the form of fried bananas. Family factor had main role in this case especially mother's role. They serve bananas in family meals as a filling snack. The dessert banana has a global distribution, considering the nutrition aspect, it is the world's leading fruit crop [21]

Based on data in table 5 , it was found that cassava is mostly highly preferred although there is no relationship between the level of education and the level of preference towards this commodity. The preference for cassava at all levels of education is generally very like. Cassava is favored by all levels of education in Kawio village, because from child has been introduced to this type of food. Another reason, the people in Kawio very like to grow cassava as a source of carbohydrate food. Cassava is easier to grow than other types of tuber.

\subsubsection{Preference levels by Age}

The age of community is one important factor to study food preference [7]. The results of the study of food preference levels based on age are presented in figure 4. 


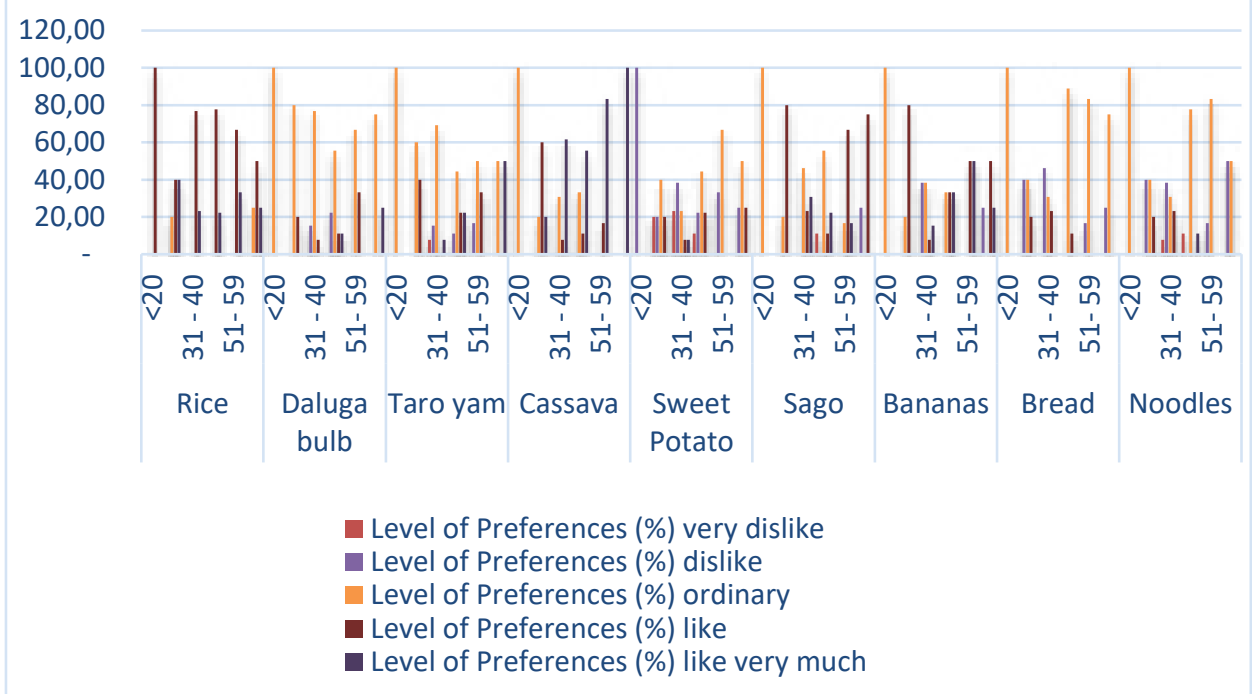

Source: Primary Data, 2017.

Fig. 4. The level of community preference for food types by age.

Figure 4 shows that the level of preference for the type of food source of carbohydrates from respondents of different tended to vary. The data presented in the picture shows the respondent's level of preference for rice and cassava spread from like to very like, on daluga tubers, bananas and bread spreads dislike until very like and on sago, sweet potato, taro and noodles spread on very dislike until very like. It is seen that the highest favorite level percentage is found in cassava with a high level of preferences at the age of 60 years and the lowest favorite level percentage in the food type noodles and taro 31-40 years, with the favorite level very disliked by $7.69 \%$. The results of the correlation analysis between age and food preference levels are presented in table 6.

Table 6. Results of correlation analysis between food preferences and age in Kawio Village

\begin{tabular}{|l|r|l|}
\hline Types of Food & $\begin{array}{l}\text { p-value } \\
\text { (r-value })\end{array}$ & Description \\
\hline Rice & $0.840(0.033)$ & Weak correlation is not significant \\
\hline Daluga tubers & $0.324(0.160)$ & Weak correlation is not significant \\
\hline taro yam & $0.216(0.200)$ & Weak correlation is not significant \\
\hline Cassava & $0.005^{* *}(0.433)$ & Correlation is significant \\
\hline Sweet potato & $0.092(0.270)$ & Moderate correlation is not significant \\
\hline Sago & $0.507(0.108)$ & Weak correlation is not significant \\
\hline Banana & $0.009^{* *}(0.409)$ & Correlation is significant \\
\hline Bread & $0.737(0.055)$ & Weak correlation is not significant \\
\hline Noodles & $0.898(-0.021)$ & Weak negative correlation is not significant \\
\hline
\end{tabular}

Description: p-value: *: significant at level $0.05 ; * *$ : significant at level 0.01

The results of the study (see Table 6) show there is a correlation between age with people's preference for cassava and banana at a moderately significant correlation with $\mathrm{p}$ values of 0.005 and 0.009 and $r$ values of 0.433 and 0.409 . The preference of the food are from ordinary to very like. A significant positive relationship occurs between the food preference 
of cassava and age $(\mathrm{p}<0.05)$, meaning that the higher the age the more preferred the type of cassava food. For bananas, the favored level increases then decreases

The increase of level preference with increasing age suitable with statement that older people' preference for local products is greater because they have come first and are very familiar with food from their home region compared to young consumers who like processed local food. [9]. One of the reasons for this difference in preference is there are different experiences with food as we grow up. Most food preferences are learned through life experience and several ways through learning about food [12]. Cassava is a type of tuber that can be used as a rice substitute. It is believed that the lack of rice production as the people's staple food may be covered by cassava due to some reasons, namely its relatively low in price, the width of the area $(168,195$ hectares $)$, the production $(3,601,074.31$ tons $)$ and productivity $(214,10 \mathrm{kw} / \mathrm{Ha})[22]$

The most important part of cassava is the storage roots, containing $65-91 \%$ starch content, depending on the variety. The nutrients in the storage root include vitamin $\mathrm{C}$, carotenoids, calcium, potassium, iron, magnesium, copper, zinc and manganese while cassava starch includes ash, protein, lipid, phosphorus and fiber content, ranging between 0.03 and $0.29 \%$, $0.06-0.75 \%, 0.01-1.2 \%, 0.0029-0.0095 \%$ and $0.11-1.9 \%$, respectively [23]. In other types of local foods such as daluga tubers, sweet potatoes, taro and rice, bread and noodles, all layers of age like it with a level of preference mostly on a regular level.

\subsubsection{Preference levels by Income per Capita}

Income is a mirror of purchasing power so the quality and quantity of goods that can be purchased also depends on purchasing power. The greater the income received, the greater the opportunity for households to choose different types of food that are more varied and improve the quality of their food by purchasing food ingredients with higher nutritional value [24].

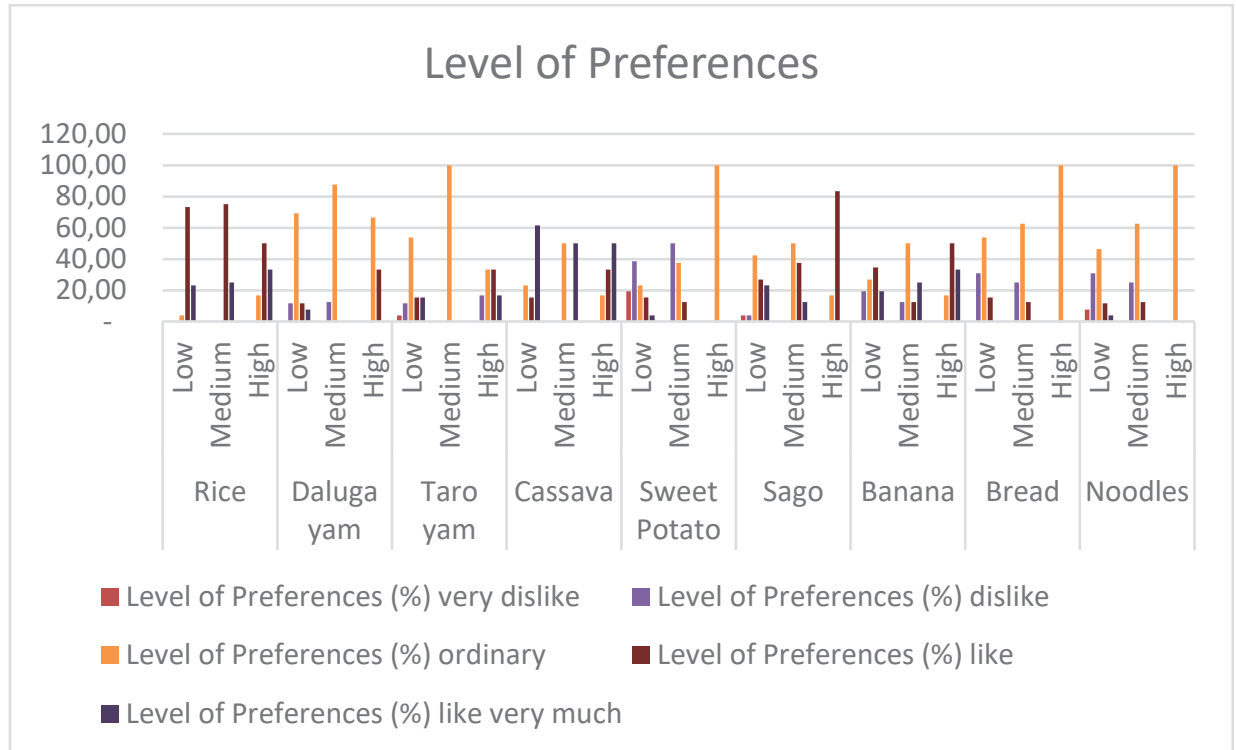

Source: Primary Data, 2017.

Fig. 5. The level of community preference for food types by income per capita 
The data presented in figure 5 shows that respondents' preferred level of carbohydrate food type tends to vary based on income level. In this type of carbohydrate food rice and cassava level of favorite respondents spread from like to very like. For daluga tubers, bananas and bread, data spread on dislike until very like and on sago, sweet potato, taro yam and noodle, data spread on very dislike until very like. The highest percentage of respondents who expressed the highest like was in the type of cassava food with a low per capita income rate of $61.54 \%$. This indicates that cassava at this income level is most preferred by respondents. The results of the correlation analysis between income level and food preference level are presented in table 7.

Table 7. Results of correlation analysis between food preferences and income per capita in Kawio Village

\begin{tabular}{|l|l|l|}
\hline Types of Food & p-value (r-value) & Description \\
\hline Rice & $0.971(0.006)$ & Weak correlation is not significant \\
\hline Daluga tubers & $0.758(0.050)$ & Weak correlation is not significant \\
\hline Sweet potato taro & $0.619(-0.081)$ & Negative correlation is not significant \\
\hline Cassava & $0.242(-0.189)$ & Negative correlation is not significant \\
\hline Sweet potato & $0.943(0.012)$ & Weak correlation is not significant \\
\hline Sago & $0.781(-0.045)$ & Negative correlation is not significant \\
\hline Banana & $0.206(0.204)$ & Weak correlation is not significant \\
\hline Bread & $0.495(0.111)$ & Weak correlation is not significant \\
\hline Noodles & $0.434(0.127)$ & Weak correlation is not significant \\
\hline
\end{tabular}

Notes: Description: $p$-value: *: significant at level 0.05 ; **: significant at level 0.01

The results of the study in Table 7 showed that there is no correlation between the income per capita of kawio people and level of food preferences. It indicates that people's income level does not affect the level of preference. This is because people have become accustomed to consuming local food, although in terms of their income is already high and the ability to buy other types of food exists. The income range of respondents is IDR 1,000,000 $5,000,000$. Consumer preferences do not depend on income and price. The ability to buy goods does not determine the likes or dislikes of consumers, but this preference is formed from the consumer's perception of the product [10]. The behavior of consumers buying a product is also due to the large amount of stock, and the consumer's behavior towards purchasing is to seek diversity, convenience and the large number of stock goods /products [24]. The fact, this was not the case at Kawio.

Every consumer must have a food preference. These preferences can be changed and learned from childhood. . Different food preferences are caused by differences in the learning experience with food, which is a psychological factor. In addition biological reactions to the foods we consume also affect our food choices and preferences; one of them is our biological reaction [12]. Food choices are also influenced by personal and cultural ideals, constrained by current resources and context. Evidence that certain environmental factors can also influence food choices such as food prices; access to food outlets offering a wide range of healthy food; and gaps in access, especially in transportation [25].

Limited transportation access to Kawio and Marore village becomes a limiting factor in the provision of food from outside. During wave season, ships transporting food supplies are difficult to dock. The community persists with the local food that exists so that people tend to like the local food that has been available in the area People are often severely constrained by transportation such as people with disabilities, so it is often entirely dependent on social networks for access to food [25]. The border community in Marore sub-district indirectly in food selection depends heavily on the food in the area, whose availability is limited by transportation. 
This is also why the influence of income and education levels does not affect food preferences on local food, including diet. The results of food preference research in border areas can show people's demand for food sources, especially carbohydrate sources, and describe the types of food that could potentially be developed in the area. The results showed that cassava is the most desirable type of food besides rice, so it needs to be developed diversification of processing instead of just focusing on traditional products. The border area with all its potentials and challenges is still very possible to realize its food independence by increasing the utilization of local food based food. Types of tubers such as cassava are one of Indonesia's most likely food potentials, as a local resource that is more resistant to variable climate change [26].

Cassava can be processed into various types of processed foods that are beneficial for health and value added for people in border areas. Local food consumption gives some advantages. It can preserve local and small-scale farmland, reduce the distance food travels, and reduce related fossil fuel consumption, air pollution, and greenhouse gas emission. Besides, it can support the preservation of the genetic diversity of local food commodity cultivars [27]. Consumers are generally open to the innovation of traditional food products; however, the preliminary study results that not all food production developments are in line with consumer accessibility. Surprisingly, the more traditional products were more liked [28]. The innovation of traditional products that are convenient and do not harm the traditional production aspect is suggested as a very viable strategy to secure a successful market position [29]. The effort to increase the community's ability to diversify local food must be carried out immediately so that people's preference is maintained.

\section{Conclusion}

Marore sub-district has local food resources in the form of tubers consisting of daluga tubers, cassava, sweet potatoes and taro, bananas and sago, but the ways of cultivation and processed products are still traditional.

The level of preference of people between Kawio and Marore villages was different. There is a significant correlation between regions, with consecutive $p$-values for daluga tuber, taro, cassava, sweet potatoes, bread and noodles. Based on the level of education there is a significant real negative correlation of preferences level 'community for bananas with $p$ value of 0.032 , based on age there are significant correlation for cassava and bananas with consecutive p-values of 0.005 and 0.009 , and based on per capita income there is no correlation for all type food..

The level of preference for food is generally from ordinary to very like in the border area of Sangihe Islands. It was influenced by the availability of food in the location both local food and other carbohydrate sources, the consumption patterns of the local community and the access of the people to get food. Cassava is the most preferred type of food besides rice, so its cultivation and post-harvest system must to be optimized. Besides that, it needs to be developed diversifying its processing, instead of just focusing on traditional products. Suggestions for policy makers are the importance of developing local food plants that are preferred by people in border areas, both in cultivation and post-harvest technology innovation in collaboration with related agencies which directly provide benefits and are sustainable. 


\section{References}

1. M. Lintang, O. Tandi, P. Layuk, J. Wenas. Loc.F.P.S Kawio Vilge. Buletin Agrosaintek. V 4, 2. (2018)

2. R. Syarief. Sumardjo, A. Fatchiya. Ass.Food Security. JIPI. 19, 9-13 (2014)

3. W Findiastuti, M.L. Singgih, Anityasari. IOP Conf. Ser.: Mater. Sci. Eng. 193012053 (2017)

4. M Semikolenova1, T Rudakova, N. Shavkunova. IOP Conf.Ser : Earth. Env. Sci. 395 012097 (2019)

5. G.D.P. Dewi, R V Yustikaningrum. IOP Conf. Ser.: Earth Environ. Sci.126 012127 (2018)

6. M. Kansiimea, J.Tambob, I. Mugambia, M. Bundia, A. Karac, C. Owuo Reg.Res. Articlecovid-19 Uganda.. World Dev. 137105199 (2020)

7. S. Martinez. M. Hand, M.D. Pra, S. Pollack, K. Ralston, T. Smith, S.Vogel, S. Clark, L. Lohr, S. Low, C. Newman. USDA-Economic Research Service (2010)

8. C. Feldmann, H. Ulrich Hamm. Cons.Percep.Rev. Food Quality and Preference 40, 152-164 (2015)

9. F.C. Coelho, E.M. Coelho, M.Egere. Loc.F: Benf.Mod.Agric. Sci. Agric,.75,1,84-94, (2018)

10. M. Lintang, P. Layuk, Bahtiar. Pot. Loc.F. Sangihe Islands. Book Of Developing Food Self-Sufficiency In Small Islands And Border Areas. AARD Press. 213-231 (2015)

11. Andriyanty, D. Wahab, Gen.Z. Cons. Pref. Journal Of Research And Community Service, 7, 2: 280-296 (2019)

12. M. Vabo, H. Hansen. Relat. F.Pref. Food Cho.International Journal of Business and Social Science, 5, 7 (2014)

13. E. Costell, A. Tarrega, S. Bayarri. F.Accept. The Role Of Cons.mer Perception And Attitudes. Chemosensory Perception, 3(1), 42-50 (2010)

14. K. Skallerud, A.H.Wien. Pref.Loc F. Help.Behav. Journal of Rural Studies 67, 79-88 (2019)

15. E.Bartkiene, Steibliene, V. Adomaitiene, G. Juodeikiene, D.Cernauskas, V.Lele, D Klupsaite, D.Zadeike, L.Jarutiene, R.P.F.Guiné. Art.Affect.Cons. F.Pref. Dep.Use Read. Techn. Biomed Research International 2097415, 10 Pages (2019)

16. W.C. Fobbs, S.J.Y. Mizumori. Us.Rod. Mdls. Neurobiology Of Learning And Memory, 139, 89-97..(2017)

17. C.Steele, J.Pirkle, I.R. Davis, Kimberly, Kirkpatrick. Diet.Effec.Determ.F.Choice Appetite, 136 160-172 (2019)

18. BPS. Marore. Marore Dist.Nbrs. (2017)

19. M. Lintang, P. Layuk, G.H. Joseph. Charact.Orig.N.Sulawesi, Subst. Wheat. Food. Journal of Post-Harvest Agric. Res. 13, 2, (2016)

20. Wynalda, R. Hidayat, F.Pref.West Kalimantan. Scientific Journal of Food Technology 4,1 10 (2017)

21. Singh, R. Kaushikand Saurabh, Gosewade. Bananas Raw Mat. For Food. The Pharma Innovation Journal 2018; 7(6): 574-580

22. R.Hanafie, Suwarta, Alfiana. Var.Charac.Proc. F.Indust.Cass. Agri.Int.Conf.Agricultural Science Procedia 9,258 - 263 (2016) 
23. F. Zhu, F. (2015). Comp. Struc.Phys.Cassava Starch. Carbohydrate Polymers, 122, 456480 (2015).

24. Kasmadi, I. Mirdhayati, E. Rahmadani. Cons.Pref.Milk Drinks In Tiga Pekanbaru City Mall. Journal Of Animal Husbandry, 8, 1,27-37. (2011)

25. J.A. Caswell, A L. Yaktine, Indv.H.Env.Affec.F.Choices . National Academies Press. 978-0-309-294-1 (2013)

26. Jarvis, Andy, J.Ramirez-Villegas, B.Herrera, C.Navarro-Racines. 2012. Tropical Plant Biology, 5,1, 9-29 (2012)

27. R. Brain. Loc.F. M.Def., Benf. Sustainability 09 (2012)

28. F. Vanhonacker, B. Kuhne, X.Gellynck, L.Guerrero, M.Hersleth, W. Verbeke. Innov.In Trad.F. Food Research International, 54,2, 1828-1835 (2013)

29. D. N. Fibria, M. Frosta. Cons.Percepti.Orig.Mod.Trad. F.Indonesia. Appetite 133, 6169 (2019) 